\title{
Elektrokémiai kutatások újabb eredményei az ELTE Elektrokémiai és Elektroanalitikai Laboratóriumban - A nanomérettartománytól a nagyteljesítményű áramforrásokig
}

\author{
UJVÁRI Mária*, VESZTERGOM Soma, INZELT György, LÁNG Győző \\ Eötvös Loránd Tudományegyetem, Kémiai Intézet, Elektrokémiai es Elektroanalitikai Laboratórium, \\ Pázmány Péter sétány 1/A, 1117 Budapest, Magyarország
}

\section{Bemutatkozás}

Az Eötvös Loránd Tudományegyetem (ELTE) Kémiai Intézetében végzett elektrokémiai kutatások eredményeit 2012. elejéig bezárólag egy korábbi cikkben foglaltuk öszsze ${ }^{1}$. Az ELTE TTK Fizikai Kémiai Tanszéke korábban e területen igen fontos szerepet töltött be, az elért eredményeket olyan nevek fémjelzik, mint Erdey-Grúz Tibor és Kiss László. A Kémiai Intézet megalakulása után az intézeti tanszékek, mint pl. a Fizikai Kémiai Tanszék, elsődleges céljává az oktatási feladatok ellátása vált, és a kutatási tevékenység súlypontja a tanszékektől függetlenül működő intézeti kutatólaboratóriumokra helyeződött át. A kutatólaboratóriumok közül az Elektrokémiai és Elektroanalitikai Laboratórium legfontosabb feladata az elektrokémiai kutatások magas színvonalú művelése, új módszerek és eljárások kidolgozása, a mérörendszerek és a gyakorlati alkalmazások folyamatos fejlesztése.

A fent korábban említett cikkben ${ }^{1}$ felhívtuk a figyelmet arra, hogy „e változások egy olyan időszakban történnek, amikor az elektrokémiai kutatások világszerte egyre inkább az érdeklődés középpontjába kerülnek, leginkább annak a vélekedésnek köszönhetően, mely szerint az elektrokémia hatékonyan hozzájárulhat a világ egyre égetőbb energiagondjainak megoldásához. Magyarországon a trend az elmúlt évtizedekben ezzel éppen ellentétes volt, az elektrokémia kutatása (és oktatása) mind a felsőoktatási intézményekben, mint az akadémiai kutatóhelyeken folyamatosan visszaszorult". A fenti megállapítások publikálása óta eltelt időszakban mindkét említett folyamat hangsúlyosabb lett. Az elektrokémiai tudományterület fontosságának növekedését jól mutatja, hogy a 2019. évi kémiai Nobel-díjjal az elektrokémiai energiatárolással kapcsolatot kutatásokat jutalmazták. Ezzel szemben Magyarországon az elektrokémiai kutatóbázis leépülése napjainkban is tart. Bár más hazai felsőoktatási intézmények tanszékeihez tartozó kutatócsoportokban is folynak nagyon sikeres, elektrokémiával kapcsolatos kutatások (ld. pl. a Fotoelektrokémiai Kutatócsoport a Szegedi Tudományegye-tem Fizikai Kémiai és Anyagtudományi Tanszékén, illetve az Energiatárolás Kutatócsoport a Budapesti Müszaki és Gazdaságtudományi Egyetem Kémiai és Környezeti Folyamatmérnöki Tanszékén), az ELTE Kémiai Intézetében működik az utolsó olyan önálló egyetemi kutatólaborató- rium, amely nevében az "elektrokémia" név az alapveto" tevékenységre utal és az itt folyó kutatómunka az elektrokémia számos területét felöleli. Az ipari kapcsolatoknak és a pályázati tevékenységnek köszönhetően a laboratóriumi munka infrastrukturális háttere magyar viszonyok között jónak mondható. A kutatási témák sorában megtalálhatók az elméleti tanulmányok (pl. a határfelületek termodinamikája), a különleges tulajdonságokkal rendelkező elektrokémiai rendszerek (pl. a módosított elektródok, vezető polimer filmek és kompozitok) vizsgálata, a környezetvédelmi szempontból fontos témák (pl. a ferrátsók elektrokémiai előállítása és alkalmazása vízkezelésre), az elektrokémiai vizsgálati módszerek fejlesztése, az elektrokatalízis tanulmányozása, és számos más gyakorlati alkalmazás (pl. az elektrokémiai áramforrások kutatása vagy az elektrokémiai módszerek alkalmazása a szerves kémiai kutatásokban). A jelen közleményben az e területeken elért eredményeinket foglaltuk össze.

\section{2. Újabb eredményeink}

\subsection{Elektrokémiai mérőrendszerek fejlesztése}

Korábbi, a Magyar Kémiai Folyóirat hasábjain megjelent munkánkban ${ }^{1}$ ismertettünk két olyan mérőrendszert, amelyek fejlesztésében az Elektrokémiai és Elektroanalitikai Laboratóriumnak fontos szerepe volt. Az egyik mérörendszer a magyarra leginkább „hajló konzol” módszernek fordítható bending beam módszer alkalmazásán alapult. A módszer elektrokémiai rendszerek vizsgálatához történő adaptációjának előfeltétele volt a megfelelő szerkezetű minták elöállítása, illetve olyan, termosztálható elektrokémiai cellák tervezése, amelyek megfelelnek a nagypontosságú optikai mérésekkel szemben támasztott követelményeknek. Az utóbbi években a bending beam módszer alkalmazásával vizsgáltunk például ruténium felületek perklórsavas közegben történt polarizációja közben kialakuló2 ${ }^{2}$ illetve fémfelületekre leválasztott polimerek degradációjának köszönhető ${ }^{3}$ felületi feszültségváltozásokat. A módszer alapjait, illetve a megvalósításhoz szükséges mérörendszer fejlesztésével kapcsolatos tapasztalatokat továbbá egy cikkben ${ }^{4}$ és egy könyvfejezetben ${ }^{5}$ is publikáltuk, a közelmúltban pedig Láng Győző társszerzőségével - egy elektródfolyamatok lézeres technikákkal történő tanulmányozásáról szóló könyv ${ }^{6}$ is megjelent.

* Főszerző. Tel.: +3613722500 ; e-mail: ujvari.maria@chem.elte.hu 
A másik, korábban már bemutatott, ${ }^{1}$ és az ELTE Elektrokémiai és Elektroanalitikai Laboratóriumában kifejlesztett mérőrendszer az ún. ,kettős voltammetria” használatát tette lehetővé forgó gyürüs korongelektródokon (rotating ring-disk electrode, RRDE). E mérörendszer, gyakorlatilag máig egyedülálló módon, lehetővé teszi az RRDE két elektródjának egymástól független, potenciodinamikus (tehát időben változó) szabályozását. Korábbi írásunk óta ${ }^{1}$ megvalósítottuk egy új, a fent említett módszerek rutinszerű alkalmazását lehetővé tevő „professzionális” mérőrendszer kifejlesztését, és kiterjesztettük a módszerek alkalmazhatósági területét. A mérörendszer fejlesztésének tapasztalatait több helyen is publikáltuk, ${ }^{7-11}$ potenciodinamikus RRDE méréseket pedig használtunk már - többek között - az arany elektródokon zajló oxigénredukció köztitermékeinek kimutatására, ${ }^{12}$ illetve a titán korróziós tulajdonságainak vizsgálatára. ${ }^{13} \mathrm{~A}$ potenciodinamikus RRDE mérések elméleti (szimulációs) vizsgálatát is elvégeztük, ${ }^{14,15}$ és új módszereket közöltünk az ún. elektromos áthallások jelenségének matematikai modellezésére. ${ }^{16,17} \mathrm{Ez}$ utóbbi módszerek egyéb többelektródos rendszerek (pl. pásztázó elektrokémiai mikroszkópia) használatakor fellépő áthallási effektusok leírására is alkalmasak.

A fentieken kívül kutatócsoportunk munkatársai részt vettek más elektrokémiai módszerfejlesztési munkákban is. Az ELTE-n például sikerrel építettünk meg egy, az UV-VIS spektroszkópiát az elektrokémiai kvarckristály nanomérleggel ötvöző mérörendszert, ${ }^{18}$ de kutatóink részt vettek - más csoportokkal közösen - mérőeszközök kifejlesztésében a molekuláris elektronika ${ }^{19}$ és a bioimpedancia spektroszkópia ${ }^{20}$ területén is.

\subsection{Elektrokémiai áramforrások}

Az 2010-es évek elején folytatott tüzelőanyag-cella kutatásaink hozama számos alapkutatási eredmény mellett egy hidrogén üzemanyaggal müködő kiserőmű illetve kisautó létrehozása volt. E kutatások folytatásaként vizsgáltuk a $\mathrm{Fe}-, \mathrm{Pd}-$, és $\mathrm{Cu}$-ftalocianin rétegek leválasztását és főként az oxigénredukcióra kifejtett katalítikus hatásukat, abból a célból, hogy a Pt katalizátort olcsóbb anyaggal váltsuk ki. ${ }^{21-26}$

Az utóbbi években az ólomakkumulátor vizsgálata került az érdeklődésünk középpontjába ${ }^{27-29}$. Vizsgáltuk a töltési-kisütési jellemzőket és a $\mathrm{PbO}_{2}$ réteg képződési és öregedési mechanizmusát a kénsavkoncentráció és elektrokémiai paraméterek függvényében. Az EQCM technika segítségével alapvetően új illetve eddig kevésbé értett jelenségek tárultak fel. Így például a géles és a kristályos részek képződésének aránya, ami alapvetően szabja meg az iontranszportot és az elektronvezetést. ${ }^{27,28} \mathrm{~A}$ kisütés (mélykisütés) közbeni belső ellenállás és hőmérsékletváltozás és az akkumulátor kapacitásvesztése között állapítottunk meg kapcsolatot. ${ }^{29}$

A Li-ion elemek esetében a katód kötőanyagának hatását tanulmányoztuk impedancia-spektroszkópiával. $\mathrm{LiFe}_{0.4} \mathrm{Mn}_{0.6}$ $\mathrm{PO}_{4}$ katód esetében egy új kötőanyag, ami poli(3,4 etilén- dioxitiofén)t, poli(sztirolszulfonát)ot és karboximetilcellulózt tartalmaz, jelentősen növeli a töltésátlépés sebességét. ${ }^{30}$

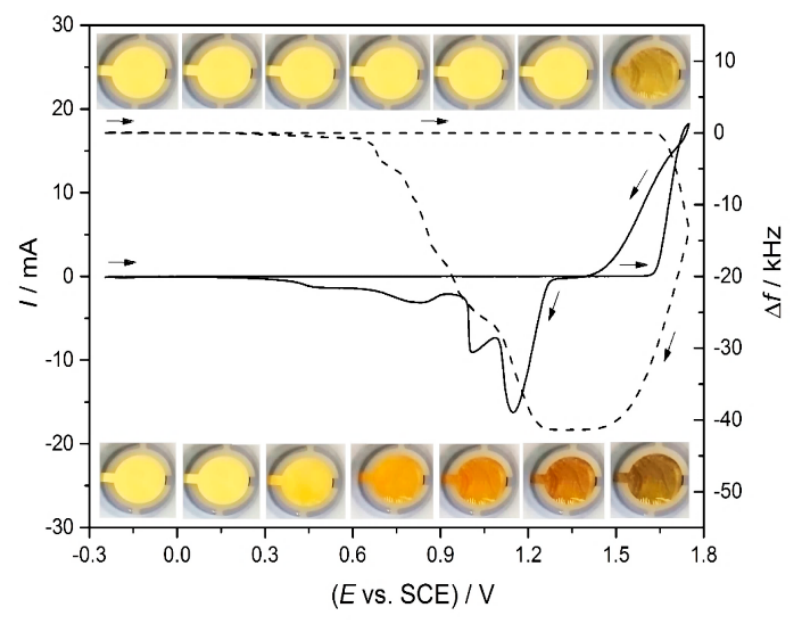

1. Ábra $\mathrm{PbO}_{2}$ réteg leválasztása kvarckristály-arany elektródra. Oldat: $0.1 \mathrm{M} \mathrm{Pb}\left(\mathrm{NO}_{3}\right)_{2}+1.0 \mathrm{M} \mathrm{HNO}_{3}$. Polarizációsebesség: $5 \mathrm{mV} \cdot \mathrm{s}^{-1}$. Ciklikus voltammogram (folytonos vonal), nanogravimetriás görbe (szaggatott vonal) és az elektród színváltozása a leválasztás (fent) és visszaoldás (lent) során. ${ }^{28}$

Szén nanocsövek és ezek vezető polimerekkel való kompozitjainak alapvető vizsgálata vezetett el ezen rendszerekből nagy, akár 500-1000 $\mathrm{F} \mathrm{g}^{-1}$ kapacitású szuperkondenzátorok előállításához. ${ }^{31}$

\subsection{Módosított elektródok}

A módosított elektródok olyan rendszerek, melyek előállítása során az elektronvezető vagy félvezető hordozóra egy új tulajdonságokkal rendelkező réteg kerül. Ezek egyik csoportja a polimerfilm-elektródok, melyeket széleskörüen használnak pl. ionszelektív elektródokban, fényemittáló diódákban, folyadékkristályos kijelzők, smart window rendszerek készítésénél, tüzelőanyag cellákban, napelemekben és más eszközökben.

A polimerfilmek közül gyakorlati szempontból kiemelkedő fontosságú poli(3,4-etiléndioxitiofén) (PEDOT) vizsgálata már nagy múltra tekint vissza laboratóriumunkban. Ennek elektrokémiai degradációjáról már írtunk előző közleményünkben ${ }^{1}$, ugyanakkor további vizsgálatokkal kimutattuk, hogy nemcsak a film porozitása változik meg a túloxidálás során, hanem rendezett szigetek jelennek meg, a polimer kristályosabb jellegüvé válik ${ }^{32-34}$.

Az oxidált film vizsgálata során megfigyelhető volt, hogy az impedancia görbék időben változnak. A spektrumok időfüggésének vizsgálata ${ }^{35-37}$ során azt tapasztaltuk, hogy oxidáció hatására az impedanciaspektrum nagyfrekvenciás tartományában látható ív átmérője megnő, majd időben csökken és az oxidáció előtti értékhez tart. Az oxidációt szintén követő kapacitáscsökkenés a spektrum állandósulása után is megmarad. Az időbeni változás egyrészt megnehezíti a fissen oxidált film különböző körülmények (potenciál, pH) közötti vizsgálatának összehasonlítását, másrészt 
ezek szigorúan véve nem is impedanciaspektrumok a mérés időtartama alatti változás miatt, ezért nem illeszthetők rá a szokásos impedanciafüggvények. Stoynov ún. „4-dimenziós" módszerének ${ }^{38}$ felhasználásával azonban nemcsak extrapolálni tudunk azokra az impedancia értékekre, amiket a mérés kezdeti időpontjában mértünk volna, de akár a mérés időtartamán kívül eső impedanciaspektrumok pontjait is megbecsülhetjük.

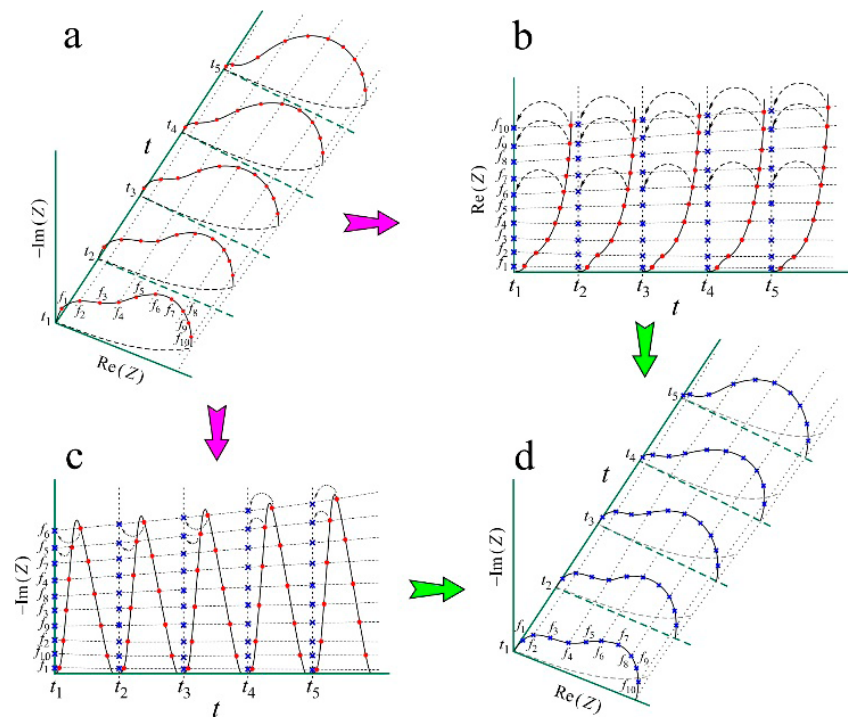

2. Ábra Az adott időpontokhoz tartozó impedanciaspektrumok kiszámításához használt eljárás sémája. A tengelyek felirataiban $t \mathrm{az}$ idő, $\operatorname{Re}(Z)$ az impedancia valós, $\operatorname{Im}(Z)$ a képzetes része.

Az EDOT-hoz (3,4-etiléndioxitiofén) nagyon hasonló az EDOP (3,4-etiléndioxipirrol), ahol az ötös gyürüben kén helyett egy NH csoport szerepel. Laboratóriumunkban ennek polimerizációját is vizsgáltuk, s azt tapasztaltuk, hogy a monomer tárolásától függően, ugyanolyan módon elöállítva, más-más tulajdonságú film keletkezett ${ }^{39}$. A frissen felhasznált monomerből készült film viselkedése kapacitív jellegü, a szubsztrát és a film közti töltésátlépési ellenállás kicsi, a keletkezett réteg viszonylag sima. A fél évig hütőben tárolt monomerből készült film voltammogramján oxidációs-redukciós csúcsok láthatóak, a töltésátlépési ellenállás ebben az esetben nagyobb, a film szerkezete érdes, gyürődésekkel, résekkel teli.

A polimerfilmek másik fontos képviselője a poliindol ${ }^{40}$, illetve ennek származékai. Az indolszármazékok karakterét nagy mértékben meghatározza az indolgyürühöz kapcsolódó funkciós csoport. Aminoszármazékainak polimerizációját és redox átalakulását kvarckristály mikromérleg segítségével vizsgáltuk. ${ }^{41-44}$ A különféle monomerekből (4-, 5- és 6-aminoindol) képződő polimereket platina és/ vagy arany hordozóra választottuk le. 4-aminoindol esetén megfigyelhető volt, hogy míg platinán a polimer spontán leválása is végbemegy, addig aranyon ilyet nem tapasztaltunk. A spontán és elektrokémiailag levált filmek tulajdonságai hasonlóak: multiréteges szerkezetűek, elegendően pozitív potenciálokon túloxidálhatók, az így keletkezett film továbbra is a felülethez kötve marad, de redox aktivitást már nem mutat.
A vezető polimerekkel kapcsolatosan két összefoglaló cikk $^{45,46}$ és egy monográfia ${ }^{47}$ is megjelent. E közlemények áttekintik a vezető polimerfilmek felfedezésének, fejlödésének történetét, bemutatják az előállításukra alkalmas módszereket, a szerkezetükkel, elektrokémiai viselkedésükkel kapcsolatos vizsgálatokat. Megtalálhatók bennük a vezető polimerek redoxi átalakulásával, túloxidációjával, és a bennük végbemenő relaxációs jelenségekkel kapcsolatos ismeretek, áttekintést nyújtanak az elektrolitoldatok összetételének, illetve $\mathrm{pH}$-jának a filmek viselkedésére gyakorolt hatásáról, továbbá a jelenlegi és potenciális jövőbeni felhasználási lehetőségekről.

Az elektródok módosítása anonban nem csak polimerekkel történhet. Az általunk kifejlesztett élesztővel módosított platinaelektródon semleges vagy gyengén alkálikus közegben a nikotinamid adenin dinukleotid $\left(\mathrm{NAD}^{+} / \mathrm{NADH}\right)$ and nikotinamid adenin dinukleotid foszfát (NADP $\left.{ }^{+} / \mathrm{NADPH}\right)$ reverzibilis redoxi viselkedést mutat, és a voltammetriás csúcsáramok a koncentrációval arányosak, tehát a NADH és a NADPH mennyiségi kimutatása lehetségessé válik. ${ }^{48}$ A poli(Cu-ftalocianin) felhasználásával pedig stabil, mechanikai hatásoknak ellenálló elektródot fejlesztettünk ki, amely kiválóan használható sav-bázis titrálásokra. ${ }^{22,23}$

\subsection{Elektrokatalitikus jelenségek vizsgálata}

Csoportunk munkássága egyre inkább kiterjed az elektrokatalízis jelenségének vizsgálatára is. A közelmúltban publikált munkáink foglalkoztak például az elektrokémiai oxigénredukció témájával, ${ }^{12,49}$ a platina felületeken lezajló adszorpciós jelenségekkel, ${ }^{50,51}$ különböző terner ötvözetek elektrokémiai leválasztásával, ${ }^{52,53}$ illetve - újabban - az elektrokémiai hidrogénfejlődés mechanizmusának vizsgálatával. ${ }^{54,55}$ Utóbbi témában eddigi legfontosabb eredményünk egy olyan új matematikai modell megalkotása, amely lehetővé teszi a híg savoldatokba merített forgó korongelektródokon mért, „lépcsős” jellegű hidrogénfejlődési polarizációs görbék leírását, és így kinetikai paraméterek meghatározását is (ld. 3. Ábra) ${ }^{55}$.



3. Ábra A hidrogénfejlődés forgó korongelektródokon, híg savakban mérhető „lépcsős” polarizációs görbéit a hidrogénfejlődést kételektronos lépésként kezelve, illetve arra az Erdey-Grúz-Volmer egyenlet érvényességét feltételezve modelleztük. A modell az autoprotolízist is kezeli, és az első analitikus formula, amellyel az így mért görbék leírhatók. ${ }^{55}$ 
Az elektrokatalízis témakörében végzett vizsgálataink jelentős része a szén-dioxid elektrokémiai redukciójának lehetőségeivel foglalkozik. Utóbbi téma kapcsán kollégáink, együttmüködésben Peter Broekmann a Berni Egyetemen müködő csoportjával, először alkalmaztak operando Raman és Röntgen-abszorpciós méréseket elektrokémiai környezetben ón-dioxid nanorészecske katalizátorok szerkezeti és kémiai változásainak vizsgálatára (ld. 4. Ábra), ${ }^{56-58}$ illetve a szén-dioxid redukcióját szerves közegekben is vizsgálták. ${ }^{59,60}$ Szintén a szerves közegü elektrokémia területéhez kötődik kollégáink egy közelmúltbeli közös publikációja Novák Zoltánnal és kutatócsoportjával (ELTE), amelyben diimin alapú réz(I) komplexek fotoredox katalitikus tulajdonságait vizsgálták. ${ }^{61}$ Mindezek mellett kollégáink részt vettek - Pajkossy Tamással (MTA Természettudományi Kutatóközpont) és Timo Jacobbal (Ulmi Egyetem) közösen - inert ionfolyadékokba merülő fémelektródok elektrokémiai kettősréteg-felépítésének vizsgálatában is, ${ }^{62-64}$ valamint tisztázták bizonyos viologén alapú, redox-aktív ionfolyadékok töltéstranszport-folyamatainak mechanizmusát is. ${ }^{65,66}$

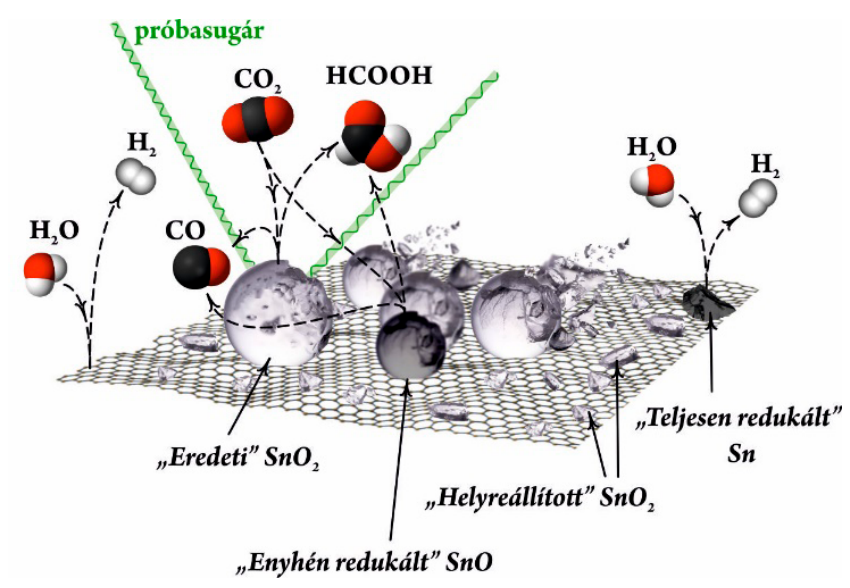

4. Ábra Ón-dioxid katalizátor nanorészecskéket szén-dioxid redukció közben vizsgáltunk operando Raman és Röntgenabszorpciós mérésekkel, feltárva a részecskék redukciójának a széndioxid redukció szelektivitását befolyásoló hatásait. ${ }^{56}$

\subsection{Az elektrokémia alkalmazása környezetvédelmi problémák megoldására}

A biológiai szennyvízkezelés során, a víztisztító rendszeren lényegi lebontás nélkül áthaladó vegyületeket tartalmazó vizek ártalmatlanítása hazánkban és nemzetközi viszonylatban is egyre nagyobb kihívást jelent. Az oxidációs elven alapuló vízkezelési módszerek a speciális, biológiailag nem, vagy nehezen lebontható szerves anyagokkal terhelt ipari szennyvizek tisztítására hatékony alternatívát nyújtanak a jelenleg alkalmazott módszerek mellett. Ezek egyike a ferrátsók alkalmazásán alapul. Természetesen ugyanezeknek a vegyületeknek az ivóvíz kezelése során is komoly szerepe lehet.

A szervetlen kémiai jellemzésük szerint a $\mathrm{Me}_{2} \mathrm{FeO}_{4}$, $\mathrm{Me}_{1} \mathrm{Me}_{2} \mathrm{FeO}_{4}$ vagy $\mathrm{MeFeO}_{4}$ összegképletü ferrátok formálisan a szabad állapotban nem ismert, vas (VI)-ot tartalmazó vassav $\left(\mathrm{H}_{2} \mathrm{FeO}_{4}\right)$ sóinak tekinthetőek. E vegyületek szilárd állapotban sötét, általában feketéslila, oldatban ibolya vagy bíborlila színüek (hígabb oldatuk rózsaszínes).

A ferrátok nagyon reaktívak, levegővel vagy vízzel érintkezve bomlanak. Ennek az az oka, hogy igen erős oxidálószerek, a vizet is lassan oxidálják (miközben vizes oldatban vas(III)-má redukálódnak). Savas, vagy semleges $\mathrm{pH}$-jú oldatokban gyorsan vagy erősen lúgos oldatokban aránylag lassan bomlanak. A stabilizált ferrát gyártása így általában nagyszámú feldolgozási lépésen keresztül történik, és jelentős szintetikus munkát követel. A szállítási és csomagolási költségek is jelentősek, hiszen az eltarthatósághoz lég- és nedvességmentes csomagolás szükséges. Ezt többnyire ampullázással oldják meg.

Kristályos állapotban a ferrát-ion tetraéderes szerkezetü, amit az 5. Ábra segítségével ábrákkal szemléltethetünk:
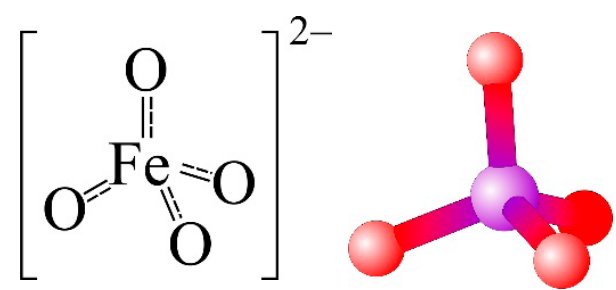

5. Ábra A ferrátion szerkezete

A ferrátok vizes oldatai színesek, ezért a fény látható hullámhossztartományában felvett spektrumok alkalmasak lehetnek a vegyületek azonosítására, illetve a koncentrációk meghatározására.

Az $\mathrm{Fe}(\mathrm{VI})$ vizes oldatokban az oldat $\mathrm{pH}$-jától függően négyféle alakban fordul elö:

$$
\begin{array}{ll}
\mathrm{H}_{3} \mathrm{FeO}_{4}^{+}=\mathrm{H}^{+}+\mathrm{H}_{2} \mathrm{FeO}_{4} & \mathrm{p} K_{\mathrm{a}}=1,6 \\
\mathrm{H}_{2} \mathrm{FeO}_{4}=\mathrm{H}^{+}+\mathrm{HFeO}_{4}^{-} & \mathrm{p} K_{\mathrm{a}}=3,5 \\
\mathrm{HFeO}_{4}^{-}=\mathrm{H}^{+}+\mathrm{FeO}_{4}^{2-} & \mathrm{p} K_{\mathrm{a}}=7,3
\end{array}
$$

A fenti adatok alapján lúgos oldatokban a $\mathrm{FeO}_{4}{ }^{2-}$-ion a domináns komponens, míg közepesen savas oldatokban inkább $\mathrm{HFeO}_{4}^{-}$van jelen. Ezzel jól magyarázható a ferrátsók instabilitása savas közegben. Fontos viszont megjegyezni, hogy a ferrátionok redukciójához tartozó elektródreakció potenciálja kisebb pH értékek esetén pozitívabb, mint erősen lúgos közegben.

$$
\begin{array}{ll}
\mathrm{FeO}_{4}^{2-}+8 \mathrm{H}^{+}+3 \mathrm{e}^{-}=\mathrm{Fe}^{3+}+4 \mathrm{H}_{2} \mathrm{O} & E_{\mathrm{r}}=2,20 \mathrm{~V} \\
\mathrm{FeO}_{4}^{2-}+4 \mathrm{H}_{2} \mathrm{O}+3 \mathrm{e}^{-}=\mathrm{Fe}(\mathrm{OH})_{3}+5 \mathrm{OH}^{-} & E_{\mathrm{r}}=0,72 \mathrm{~V} \\
\mathrm{HFeO}_{4}^{-}+\mathrm{H}_{2} \mathrm{O}+3 \mathrm{e}^{-}=\mathrm{FeO}_{2}^{-}+3 \mathrm{OH}^{-} & E_{\mathrm{r}}=0,55 \mathrm{~V}
\end{array}
$$

A szakirodalomban a ferrátok vízkezelésben történő alkalmazására gyakran a $9<\mathrm{pH}<10$ tartományt javasolják, mivel itt az elektródreakció (oxidációs) potenciálja kevésbé pozitív ugyan, viszont a Fe(VI) szpéciesz stabilabb. 
E területen az általunk végzett kutatómunka legfontosabb eredménye egy olyan elektrokémiai előállítási módszer kidolgozása, amellyel a vízkezelési kísérletekhez nagy menynyiségben tudunk ferrátsókat (nátrium- illetve kálium-ferrátot) biztosítani ${ }^{67}$, akár úgy is, hogy azokat a helyszínen állítjuk elő. A ferrátionok vízkezelésben történő alkalmazhatóságát jól demonstrálják a triklór-etilén (TCE) felszín alatti vizekböl történő eltávolítását modellező kísérletek ${ }^{68}$, amelyek során a kezelés módszer hatékonyságát partnereink a kezdeti TCE koncentrációk, a hozzáadott ferrátsók mennyisége, illetve a pH függvényében vizsgálták. A TCE koncentrációnak időbeni változását a folyadékfázisban és a gözfázisban is kombinált tömegspektroszkópiás és kromatográfiás módszerekkel követték. A ferrátos kezelés optimális $\mathrm{pH}$ értéke az eredmények alapján $\mathrm{pH}=7$, viszont az adagolandó ferrátsó mennyisége erősen függ a szennyezett víz (oldat) összetételétől.

A rendkívül szennyezett talajvíz ferrátos kezelésével elérhető eredményeket összefoglaló tanulmány ${ }^{69} 44$ szerves szennyező anyag degradációjának követésével foglalkozik. A laboratóriumi körülmények között végzett mérések eredményei alapját képezhetik az ipari léptékü technológia kidolgozásának.

Egy további közlemény a ferrátsókkal és a termikusan aktivált perszulfátionokkal történő, a mono- és triklór-benzolok talajvízből történő eltávolítását célzó kísérletek eredményeit foglalja össze ${ }^{70}$. Kimutatható volt, hogy négyféle klórbenzolt tartalmazó rendszerek esetén az eljárás 1,2-diklór-benzolra (1,2-DCB) és monoklór benzolra (MCB) vonatkozóan a leghatékonyabb. A ferrátos technológia előnyeit jelzi, hogy közel azonos anyagmennyiség arányok mellett történő alkalmazásakor nagyobb eltávolítási hatékonyság volt elérhető, mint a perszulfátos technológia esetében, emellett a zavaró ionok jelenlétére is kevésbé volt érzékeny.

A talajvíz és a felszíni vizek perklorát-szennyezése is sok országban okoz környezetvédelmi problémákat. A perklorátionok a vizekbe ammónium-, ólom-, magnézium- vagy kálium sók oldódása során kerülnek. Minthogy a perklorát lebomlása, kémiai redukciója természetes körülmények között igen lassú folyamat, a perklorátok rendkívül mobilisak vizes közegekben, és tipikus talaj- és felszíni vízi körülmények között évtizedekig megmaradnak. A szennyezés egyik fő forrása az ammónium-perklorát, ami szilárd hajtóanyagú rakétákban, lövedékekben, áramforrásokban és tüzijátékokban előszeretettel alkalmazott oxidálószer. A legsúlyosabb egészségügyi kockázat azzal a ténnyel kapcsolatos, hogy a perklorát gátolja a jódfelvételt a pajzsmirigyben. A perklorátionok elektrokémiai redukciója a perklorátszennyeződés megszüntetésének/csökkentésének egyik alternatív útja lehet.

A perklorátionok elektrokémiai stabilitásának vizsgálatát célzó kutatásaink újabb eredményei közül említést érdemelnek a ruténiumon végzett mérések eredményei ${ }^{71,72}$, illetve a korábbi eredmények összefoglalását tartalmazó közlemény ${ }^{73}$.

Az elmúlt évtized kutatásai alapján kiderült, hogy a palackokhoz és más háztartási tárgyakhoz használt polikarbonát műanyagok adaléka, a biszfenol-A (BPA) nevü vegyület tovább maradhat az emberi szervezetben, mint azt korábban gondolták. Ez oda vezetett, hogy az Európai Élelmiszerbiztonsági Hatóság (EFSA) 2018-ban szakértői csoportot állított fel a BPA veszélyességének ismételt vizsgálatára. Ismeretes, hogy míg az üdítőitalokat és ásványvizeket legtöbbször PET palackokba töltik, nagyobb mechanikai szilárdság, tartósság, illetve többszöri felhasználhatóság igénye esetén ez a műanyag-típus nem a legjobb megoldás a tárolásra. Ilyenkor polikarbonátokat szoktak használni, amelynek gyártása során a biszfenol-A-t is felhasználnak. A képet árnyalja, hogy az élelmiszeripar gyakran használ olyan bevonatot a fémdobozok belsejében is, amelyeknek szintén alapanyaga lehet a BPA. Sajnos a müanyag tárgyakon általában nincs olyan jelzés, amely egyértelmüen beazonosítaná a BPA-t, de ha a PC jelzést látjuk, vagy a háromszög jelben a 7-es számot, akkor polikarbonáttal van dolgunk, amelyből nagy valószínüséggel BPA oldódhat ki.

A BPA elektrokémia viselkedését vizes nátrium-perklorát oldatokban ciklikus voltammetria $(\mathrm{CV})$, elektrokémiai kvarc kristály mikromérleg (EQCM), elektrokémiai impedanciaspektroszkópia (EIS) és pásztázó elektronmikroszkópia (SEM) alkalmazásával tanulmányoztuk ${ }^{74,75}$. A kísérletek alapján megállapítottuk, hogy arany felületeken a BPA monomer polimerizációja és degradációja az elektrokémiai oxidáció során egyidejüleg megy végbe. A képződött polimer film morfológiáját pásztázó elektronmikroszkóp segítségével vizsgáltuk meg. A kísérleti eredmények összhangban vannak azzal a korábbi megállapítással, hogy az elektródpotenciál periodikus változtatása során $(\mathrm{CV})$ egy erősen tapadó, vékony polimer réteg alakul ki az elektród felületén. Az impedanciamérések arra utalnak, hogy a polimer elektrokémiailag gyakorlatilag inaktív a vizsgált potenciáltartományban. Az elektronmikroszkópos felvételek szerint a polimer réteg felülete meglehetösen sima, eltekintve néhány apró lyuktól és repedéstől.

\subsection{Az elektrokémia elméleti hátterével kapcsolatos eredmények}

Csoportunk az elektrokémia és elektroanalitika korszerü elméletének fejlesztéséhez is aktívan hozzájárult. Kollégáink a közelmúltban részt vettek például a transzport és a töltésátlépés alapvető összefüggéseit tisztázó cikkek, ${ }^{76-78}$ a termodinamika bizonyos elméleti problémáival foglalkozó könyvfejezetek, ${ }^{79-82}$ valamint több kémiatörténeti témájú munka ${ }^{83-87}$ megírásában is; a 2012-ben Allan J. Bard és Fritz Scholz mellett Inzelt György szerkesztette Electrochemical Dictionary c. könyv pedig megjelenése óta az egyik legygyakrabban hivatkozott elektrokémiai tárgyú forrás. ${ }^{88}$ 


\section{Köszönetnyilvánítás}

A fenti közleményben összefoglalt eredményeket az ELTE Felsőoktatási Intézményi Kiválósági Program (1783-3/2018/FEKUTSRAT), az Emberi Erőforrások Minisztériuma Új Nemzeti Kiválóság Programjának (ÚNKP-16-3, ÚNKP-17-3, ÚNKP-18-3, ÚNKP-19-3) és a Nemzeti Kutatási, Fejlesztési és Innovációs Hivatal (K 100149, K 129210, K 109036, PD 124079) támogatásával értük el. A VEKOP-2.3.2-16-2017-00013 projekt keretében folyó kutatásokat az Európai Unió és Magyarország Kormánya támogatta az Európai Regionális Fejlesztési Alap hozzájárulásával.

\section{Hivatkozások}

1. Ujvári, M.; Vesztergom, S.; Láng, G. G. Elektrokémiai mérörendszerek és kísérleti módszerek fejlesztése, elektródfolyamatok tanulmányozása. Magy. Kémiai Folyóirat 2012, 118, 120-128.

2. Ujvári, M.; Vesztergom, S.; Pénzes, C. B.; Láng, G. G. Changes of the Interfacial Stress with Electrode Potential in the $\mathrm{Ru} \mid 0.1 \mathrm{M}$ Perchloric Acid System. Electrochem. commun. 2013, 28, 111-113.

https://doi.org/10.1016/j.electacta.2012.01.068

3. Láng, G. G.; Ujvári, M.; Bazsó, F.; Vesztergom, S.; Újhelyi, F. In Situ Monitoring of the Electrochemical Degradation of Polymer Films on Metals Using the Bending Beam Method and Impedance Spectroscopy. Electrochim. Acta 2012, 73, $59-69$. https://doi.org/10.1016/j.electacta.2012.01.068

4. Láng, G. G.; Kovács, N.; Vesztergom, S.; Ujvári, M.; Zalka, D.; Szekeres, K. Experimental Methods for the Determination of Stress Changes at Electrified Solid-Liquid Interfaces. Tech. Mess. 2017, 84, 644-658. https://doi.org/10.1515/teme-2016-0082

5. Láng, G. G. Interface Stress Measurements in an Electrochemical Environment. In Encyclopedia of Interfacial Chemistry; K. Wandelt, Ed.; 2018; pp 195-206. ISBN 9780128097397 https://doi.org/10.1016/B978-0-12-409547-2.13620-0

6. Láng, G. G.; Barbero, C. Laser Techniques for the Study of Electrode Processes; Springer (Monographs in Electrochemistry): Berlin-Heidelberg, 2012. https://doi.org/10.1007/978-3-642-27651-4

7. Vesztergom, S.; Láng, G. G. The Construction of a Novel Electrochemical Measuring System for Enhanced RRDE Experiments. J. Instrum. Sci. Technol. 2013, 41, 82-95. https://doi.org/10.1080/10739149.2012.717329

8. Vesztergom, S.; Ujvári, M.; Láng, G. G. Dual Cyclic Voltammetry with Rotating Ring-Disk Electrodes. Electrochim. Acta 2013, 110, 49-55. https://doi.org/10.1016/j.electacta.2013.01.142

9. N. Kovács, M. Ujvári, G.G. Láng, P. Broekmann and S. Vesztergom, Characterization of the Capacitance of a Rotating Ring-Disk Electrode. Instrum. Sci. Technol. 2015, 43, 633-648. https://doi.org/10.1080/10739149.2015.1038561

10. Vesztergom, S.; Kovács, N.; Ujvári, M.; Láng, G. G. Apparatus and Methods for Using a Rotating Ring-Disk Electrode with Potentiodynamic Control of Both Working Electrodes. Tech. Mess. 2017, 84, 683-696. https://doi.org/10.1515/teme-2016-0083
11. Vesztergom, S.; Ujvári, M.; Láng, G. G. Dual Dynamic Voltammetry with Rotating Ring-Disk Electrodes. In Voltammetry: Theory, Types and Application; Saito, Y., Kikuchi, T., Eds.; NOVA Science Publishers: New York, 2013; pp 249-268.

https://doi.org/10.1016/j.electacta.2013.01.142

12. Vesztergom, S.; Ujvári, M.; Láng, G. G. RRDE Experiments with Independent Potential Scans at the Ring and Disk Electrodes - 3D Map of Intermediates and Products of Electrode Processes. Electrochem. Commun. 2012, 19, 1-4. https://doi.org/10.1016/j.elecom.2012.03.006

13. Kovács, N.; Sziráki, L.; Vesztergom, S.; Láng, G. Investigating Products of Titanium Dissolution in the Presence of Fluoride Ions with Dual Dynamic Voltammetry. J. Electrochem. Sci. Eng. 2018, 8, 141-149. https://doi.org/10.5599/jese.502

14. Vesztergom, S.; Barankai, N.; Kovács, N.; Ujvári, M.; Wandlowski, T.; Láng, G. G. Rotating Ring-Disk Electrode with Dual Dynamic Potential Control: Theory and Practice. Acta Chim. Slov. 2014, 61, 223-232.

15. Vesztergom, S. Rotating Disk and Ring-Disk Electrodes. In Encyclopedia of Interfacial Chemistry; Wandelt, K., Ed.; 2018; pp 421-444. ISBN 9780128097397 https://doi.org/10.1016/B978-0-12-409547-2.13563-2

16. Vesztergom, S.; Barankai, N.; Kovács, N.; Ujvári, M.; Broekmann, P.; Siegenthaler, H.; Láng, G. G. Electrical Cross-Talk in Rotating Ring-Disk Experiments. Electrochem. Commun. 2016, 68, 54-58. https://doi.org/10.1016/j.elecom.2016.04.012

17. Vesztergom, S.; Barankai, N.; Kovács, N.; Ujvári, M.; Siegenthaler, H.; Broekmann, P.; Láng, G. G. Electrical Cross-Talk in Four-Electrode Experiments: A Digital Simulation Approach to the Example of Rotating Ring-Disk Electrodes. J. Solid State Electrochem. 2016, 20, 3165-3177. https://doi.org/10.1007/s10008-016-3294-4

18. Berkes, B. B.; Vesztergom, S.; Inzelt, G. Combination of Nanogravimetry and Visible Spectroscopy: A Tool for the Better Understanding of Electrochemical Processes. $J$. Electroanal. Chem. 2013, 719, 41-46. https://doi.org/10.1016/j.jelechem.2014.01.031

19. Baghernejad, M.; Zhao, X.; Ornso, K. B.; Füeg, M.; MorenoGarcía, P.; Rudnev, A. V.; Kaliginedi, V.; Vesztergom, S.; Huang, C.; Hong, W.; et al. Electrochemical Control of Single-Molecule Conductance by Fermi-Level Tuning and Conjugation Switching. J. Am. Chem. Soc. 2014, 136, 17922-17925. https://doi.org/10.1021/ja510335z

20. Balmer, T. W.; Vesztergom, S.; Broekmann, P.; Stahel, A.; Büchler, P. Characterization of the Electrical Conductivity of Bone and Its Correlation to Osseous Structure. Sci. Rep. 2018, 8,8601 . https://doi.org/10.1038/s41598-018-26836-0

21. Inzelt, G.; Nemes, A.; Sajti, A. Study of the Surface Mass Changes during the Redox Transformations of Copper(II) Phthalocyanine-Tetrasulfonic Acid on Gold in Acidic Media. J. Solid State Electrochem. 2017, 21, 1725-1732. https://doi.org/10.1007/s10008-017-3547-x

22. Borsos, K.; Inzelt, G. A New Electrode for Acid-Base Titration Based on Poly(Copper Phthalocyanine). J. Solid State Electrochem. 2016, 20 (1215-1222). https://doi.org/10.1007/s10008-015-2899-3

23. Inzelt, G.; Borsos, K. Replacement of the Glass Electrode by Graphite at Acid-Base Potentiometric Titrations. Stud. Univ. Babes-Bolyai Chem. 2015, 60, 23-30.

24. Borsos, K.; Inzelt, G. Electrochemical and Nanogravimetric Studies of Poly(Copper Phthalocyanine) Microparticles Immobilized on Gold in Aqueous Solutions. J. Solid State Electrochem. 2015, 19, 2565-2577. https://doi.org/10.1007/s10008-015-2770-6 
25. Nemes, Á.; Inzelt, G. Electrochemical and Nanogravimetric Studies of Iron Phthalocyanine Microparticles Immobilized on Gold in Acidic and Neutral Media. J. Solid State Electrochem. 2014, 18, 3327-3337. https://doi.org/10.1007/s10008-014-2643-4

26. Nemes, Á.; Moore, C. E.; Inzelt, G. Electrochemical and Nanogravimetric Studies of Palladium Phthalocyanine Microcrystals. J. Serbian Chem. Soc. 2013, 78, 2017-2037. https://doi.org/10.2298/JSC130909094N

27. Broda, B.; Inzelt, G. Investigation of the Electrochemical Behaviour of Lead Dioxide in Aqueous Sulfuric Acid Solutions by Using the in Situ EQCM Technique. J. Solid State Electrochem. 2020, 24, 1-10. https://doi.org/10.1007/s10008-019-04450-y

28. Broda, B.; Inzelt, G. Microgravimetric Study of Electrodeposition and Dissolution of Lead Dioxide on Gold and Platinum Substrates. J. Solid State Electrochem. 2018, 22, 3921-3931. https://doi.org/10.1007/s10008-018-4097-6

29. Broda, B.; Inzelt, G. Internal Resistance and Temperature Change during Over-Discharge of Lead-Acid Battery. $J$. Electrochem. Sci. Eng. 2018, 8, 129-139. https://doi.org/10.5599/jese.469

30. Apraksin, R. V.; Eliseeva, S. N.; Kamenskii, M. A.; Tolstopyatova, E. G.; Láng, G. G.; Kondrat'ev, V. V. Impedance of $\mathrm{LiFe}_{0.4} \mathrm{Mn}_{0.6} \mathrm{PO}_{4}$ Electrodes with Combined Conducting Polymer Binder of PEDOT:PSS and Carboxymethyl Cellulose. Russ. J. Electrochem. 2019, 55, 1047-1057. https://doi.org/10.1134/S1023193519110028

31. Moore, C. E.; Inzelt, G. Electrochemical Nanogravimetric Study on the Sorption Processes Occurring in Multiwalled Carbon Nanotube Layers Immobilized on a Gold Surface. $J$. Solid State Electrochem. 2015, 19, 45-56. https://doi.org/10.1007/s10008-014-2532-x

32. Láng, G. G.; Ujvári, M.; Vesztergom, S.; Kondratiev, V.; Gubicza, J.; Szekeres, K. J. The Electrochemical Degradation of Poly(3,4-Ethylenedioxythiophene) Films Electrodeposited from Aqueous Solutions. Zeitschrift fur Phys. Chemie 2016, 281 (9), 1281-1302. https://doi.org/10.1515/zpch-2016-0752

33. Ujvári, M.; Láng, G. G.; Vesztergom, S.; Szekeres, K. J.; Kovács, N.; Gubicza, J. Structural Changes during the Overoxidation of Electrochemically Deposited Poly(3,4Ethylenedioxythiophene) Films. J. Electrochem. Sci. Eng. 2016, 6 (1), 77-89. https://doi.org/10.5599/jese. 225

34. Láng, G. G.; Kondratiev, V.; Ujvári, M.; Vesztergom, S.; Szekeres, K.; Zalka, D. Structural Changes During the Overoxidation of Poly(3,4-Ethylenedioxythiophene) Films Electrodeposited from Surfactant-Free Aqueous Solutions. In Encyclopedia of Interfacial Chemistry; Wandelt, K., Ed.; 2018; pp 258-270. ISBN 9780128098943 https://doi.org/10.1016/B978-0-12-409547-2.13301-3

35. Zalka, D.; Vesztergom, S.; Ujvári, M.; Láng, G. G. Electrochemical Behaviour of Poly $(3,4-$ Ethylenedioxytiophene) Modified Glassy Carbon Electrodes after Overoxidation - the Influence of the Substrate on the Charge Transfer Resistance. J. Electrochem. Sci. Eng. 2018, $8,151-162$. https://doi.org/10.5599/jese. 508

36. Zalka, D.; Kovács, N.; Szekeres, K.; Ujvári, M.; Vesztergom, S.; Eliseeva, S.; Kondratiev, V.; Láng, G. G. Determination of the Charge Transfer Resistance of Poly(3,4Ethylenedioxythiophene)-Modified Electrodes Immediately after Overoxidation. Electrochim. Acta 2017, 247, 321-332. https://doi.org/10.1016/j.electacta.2017.06.177
37. Ujvári, M.; Zalka, D.; Vesztergom, S.; Eliseeva, S.; Kondratiev, V.; Láng, G. G. Electrochemical Impedance Measurements in Non-Stationary Systems - Application of the 4-Dimensional Analysis Method for the Impedance Analysis of Overoxidized Poly(3,4Ethylenedioxythiophene)-Modified Electrodes. Bulg. Chem. Commun. 2017, 49, 106-113.

38. Savova-Stoynov, B.; Stoynov, Z. Four-dimensional estimation of the instantaneous impedance, Electrochim. Acta 1992, 37, 2353-2355. https://doi.org/10.1016/0013-4686(92)85131-4

39. Szekeres, K. J.; Hegedüs, K.; Ujvári, M.; Láng, G. G. Investigation of the Electrochemical Properties of Poly(3,4Ethylenedioxypyrrole) Films Electrodeposited from Aqueous Solutions. J. Electroanal. Chem. 2018, 826, 16-22. https://doi.org/10.1016/j.jelechem.2018.08.017

40. Berkes, B. B.; Bandarenka, A. S.; Inzelt, G. Electropolymerization: Further Insight into the Formation of Conducting Polyindole Thin Films. J. Phys. Chem. 2015, 119, 1996-2003. https://doi.org/10.1021/jp512208s

41. Berkes, B. B.; Nemes, Á.; Moore, C. E.; Szabó, F.; Inzelt, G. Electrochemical Nanogravimetric Study of the Electropolymerization of 6-Aminoindole and the Redox Transformations of the Polymer Formed in Aqueous Media. J. Solid-State Electrochem. 2013, 17, 3067-3074. https://doi.org/10.1007/s10008-013-2132-1

42. Berkes, B. B.; Inzelt, G.; Vass, E. Electrochemical Nanogravimetric Study of the Adsorption of 4-Aminoindole and the Surface Layer Formed by Electrooxidation in Aqueous Acid Media. Electrochim. Acta 2013, 96, 51-60. https://doi.org/10.1016/j.electacta.2013.02.080

43. Broda, B.; Inzelt, G. Preparation and Characterization of Poly(5-Aminoindole) by Using Electrochemical Quartz Crystal Nanobalance Technique. Acta Chim. Slov. 2014, 61, 357-365.

44. Berkes, B. B.; Inzelt, G. Electrochemical Nanogravimetric Studies on the Electropolymerization of Indole and on Polyindole. Electrochim. Acta 2014, 122, 11-15. https://doi.org/10.1016/j.electacta.2013.06.035

45. Inzelt, G. Conducting Polymers: Past, Present, Future. $J$. Electrochem. Sci. Eng. 2018, 8, 3-37. https://doi.org/10.5599/jese.448

46. Inzelt, G. Recent Advances in the Field of Conducting Polymers. J. Solid State Electrochem. 2017, 21, 1965-1975. https://doi.org/10.1007/s10008-017-3611-6

47. Inzelt, G. Conducting Polymers-A New Era in Electrochemistry, 2nd ed.; Scholz, F., Ed.; Springer (Monographs in Electrochemistry): Berlin-Heidelberg, 2012.

https://doi.org/10.1007/978-3-642-27621-7

48. Róka, A.; Inzelt, G. Cyclic Voltammetric and Nanogravimetric Studies of NADP ${ }^{+}$Redox Transformations on a Yeast-Modified Platinum Electrode. Electrochem. Commun. 2014, 45, 9-12. https://doi.org/10.1016/j.elecom.2014.05.006

49. Kriston, Á.; Berkes, B. B.; Simon, P. L.; Inzelt, G.; Dobos, K.; Nemes, Á. Unusual Surface Mass Changes in the Course of the Oxygen Reduction Reaction on Platinum and Their Explanation by Using a Kinetic Model. J. Solid State Electrochem. 2012, 16, 1723-1732.

https://doi.org/10.1007/s10008-011-1582-6

50. Berkes, B. B.; Inzelt, G. Generation and Electrochemical Nanogravimetric Response of the Third Anodic Hydrogen Peak on a Platinum Electrode in Sulfuric Acid Media. $J$. Solid State Electrochem. 2014, 122, 11-15. https://doi.org/10.1007/s10008-013-2164-6 
51. Berkes, B. B.; Schuhmann, W.; Inzelt, G.; Bondarenko, A. S. Influence of $\mathrm{Cs}^{+}$and $\mathrm{Na}^{+}$on Specific Adsorption of $* \mathrm{OH}$, ${ }^{*} \mathrm{O}$, and ${ }^{*} \mathrm{H}$ at Platinum in Acidic Sulfuric Media. J. Phys. Chem. 2012, 116, 10995-11003. https://doi.org/10.1021/jp300863z

52. Stichleutner, S.; Kuzmann, E.; Lak, G. B.; El-Sharif, M.; Chisholm, C. U.; Havancsák, K.; Skuratov, V. A.; Sziráki, L.; Homonnay, Z.; Vértes, A. Effect of Swift Heavy Ion Irradiation on the Short Range Order in Novel Electrodeposited Ternary Amorphous Alloys. Radiat. Phys. Chem. 2013, 91, 166-169.

https://doi.org/10.1016/j.radphyschem.2013.05.014

53. Lak, G. B.; Kuzmann, E.; El-Sharif, M.; Chisholm, C. U.; Stichleutner, S.; Homonnay, Z.; Sziráki, L. Galvanostatic Charge-Discharge Tests, ${ }^{57} \mathrm{Fe}$ and ${ }^{119} \mathrm{Sn}$ Mössbauer and XRD Measurements on Novel Sn-Ni-Fe Electrodeposits. Hyperfine Interact. 2013, 218, 145-150.

https://doi.org/10.1007/s10751-012-0693-5

54. Grozovski, V.; Vesztergom, S.; Láng, G. G.; Broekmann, P. Electrochemical Hydrogen Evolution: $\mathrm{H}^{+}$or $\mathrm{H}_{2} \mathrm{O}$ Reduction? A Rotating Disk Electrode Study. J. Electrochem. Soc. 2017, $164,3171-3178$. https://doi.org/10.1149/2.0191711jes

55. Gálvez-Vázquez, M. de J.; Grozovski, V.; Kovács, N.; Broekmann, P.; Vesztergom, S. Full Model for the Two-Step Polarization Curves of Hydrogen Evolution, Measured on RDEs in Dilute Acid Solutions. J. Phys. Chem. C 2020, 124, 3988-4000. https://doi.org/10.1021/acs.jpcc.9b11337

56. Dutta, A.; Kuzume, A.; Kaliginedi, V.; Rahaman, M.; Sinev, I.; Ahmadi, M.; Cuenya, B. R.; Vesztergom, S.; Broekmann, P. Probing the Chemical State of Tin Oxide NP Catalysts during $\mathrm{CO}_{2}$ Electroreduction: A Complementary Operando Approach. Nano Energy 2018, 53, 828-840. https://doi.org/10.1016/j.nanoen.2018.09.033

57. Dutta, A.; Kuzume, A.; Rahaman, M.; Vesztergom, S.; Broekmann, P. Monitoring the Chemical State of Catalysts for $\mathrm{CO}_{2}$ Electroreduction: An In Operando Study. $A C S$ Catal. 2015, 5, 7498-7502. https://doi.org/10.1021/acscatal.5b02322

58. Kuzume, A.; Dutta, A.; Vesztergom, S.; Broekmann, P. Operando Raman Spectroscopy: Studies on the Reactivity and Stability of $\mathrm{SnO}_{2}$ Nanoparticles During Electrochemical $\mathrm{CO}_{2}$ Reduction Reaction. In Encyclopedia of Interfacial Chemistry; Wandelt, K., Ed.; 2018; pp 217-226. https://doi.org/10.1016/B978-0-12-409547-2.13300-1

59. Rudnev, A. V.; Fu, Y.-C.; Gjuroski, I.; Stricker, F.; Furrer, J.; Kovács, N.; Vesztergom, S.; Broekmann, P. Transport Matters: Boosting $\mathrm{CO}_{2}$ Electroreduction in Mixtures of $[\mathrm{BMIm}]\left[\mathrm{BF}_{4}\right] /$ Water by Enhanced Diffusion. ChemPhysChem 2017, 18, 3153-3162. https://doi.org/10.1002/cphc.201700737

60. Rudnev, A. V.; Zhumaev, U.; Kuzume, A.; Vesztergom, S.; Furrer, J.; Broekmann, P.; Wandlowski, T. The Promoting Effect of Water on the Electroreduction of $\mathrm{CO}_{2}$ in Acetonitrile. Electrochim. Acta 2016, 189, 38-44. https://doi.org/10.1016/j.electacta.2015.12.088

61. Földesi, T.; Sipos, G.; Adamik, R.; Nagy, B.; Tóth, B. L.; Bényei, A.; Szekeres, K. J.; Láng, G. G.; Demeter, A.; Peelen, T. J.; et al. Design and Application of Diimine-Based Copper(I) Complexes in Photoredox Catalysis. Org. Biomol. Chem. 2019, 17, 8343-8347. https://doi.org/10.1039/C9OB01331H

62. Müller, C.; Németh, K.; S. Vesztergom, T.; Pajkossy, .; Jacob, T. The Interface between HOPG and 1-Butyl-3Methyl-Imidazolium Hexafluorophosphate. Phys. Chem. Chem. Phys. 2016, 18, 916-925.

https://doi.org/10.1039/C5CP05406K
63. Müller, C.; Vesztergom, S.; Pajkossy, T.; Jacob, T. Immersion Measurements of Potential of Zero Total Charge (Pztc) of $\mathrm{Au}(100)$ in an Ionic Liquid. Electrochim. Acta 2016, 188, $512-515$. https://doi.org/10.1016/j.electacta.2015.11.141

64. Müller, C.; Vesztergom, S.; Pajkossy, T.; Jacob, T. The Interface between $\mathrm{Au}(100)$ and 1-Butyl-3-MethylImidazolium-Bis(Trifluoromethylsulfonyl)Imide. $J$. Electroanal. Chem. 2015, 737, 218-225. https://doi.org/10.1016/j.jelechem.2014.06.010

65. Bodappa, N.; Broekmann, P.; Fu, Y.-C.; Furrer, J.; Furue, Y.; Sagara, T.; Siegenthaler, H.; Tahara, H.; Vesztergom, S.; Zick, K.; et al. Temperature-Dependent Transport Properties of a Redox-Active Ionic Liquid with a Viologen Group. $J$. Phys. Chem. C 2015, 119, 1067-1077. https://doi.org/10.1021/jp509931p

66. Bodappa, N.; Fu, Y.-C.; Broekmann, P.; Furrer, J.; Zick, K.; Vesztergom, S.; Tahara, H.; Sagara, T. Electron Transfer Controlled by Solvent and Counter-Anion Dynamics in Electrochemistry of Viologen-Type Ionic Liquid. Electrochim. Acta 2019, 320, 134559. https://doi.org/10.1016/j.electacta.2019.134559

67. Láng, Győző ; Varga, József ; Záray, Gyula ; Varga, Imre Péter Berendezés és eljárás nátrium- és kálium-ferrát oldatok elektrokémiai módszerrel történő előállítására. Szabadalmi Közlöny és Védjegyértesitő 2018, 123. P10-P11. Ügyszám: P 1600474, lajstromszám: 231043, 2020.

68. Dobosy, P.; Vizsolyi, É. C.; Varga, I.; Varga, J.; Láng, G. G.; Záray, G. Trichloroethylene Removal from Water by Ferrate Treatment. Microchem. J. 2016, 127, 74-78. https://doi.org/10.1016/j.microc.2016.02.010

69. Vizsolyi, É. C.; Dobosy, P.; Láng, G. G.; Varga, I.; Varga, J.; Záray, G. Laboratory Scale Study for Remediation of Polluted Groundwater by Ferrate Treatment. Microchem. J. 2017, 133, 231-236. https://doi.org/10.1016/j.microc.2017.03.042

70. Dobosy, P.; Vizsolyi, C. É.; Varga, I.; Varga, J.; Láng, G.; Záray, G. Comparative Study of Ferrate and Thermally Activated Persulfate Treatments for Removal of Mono- and Dichlorobenzenes from Groundwater. Microchem. J. 2018, $136,61-66$. https://doi.org/10.1016/j.microc.2016.10.015

71. Láng, G. G.; Ujvári, M.; Vesztergom, S. Electrochemical Reduction of Perchlorate Ions on Ruthenium. Acta Chim. Slov. 2014, 61, 233-240.

72. Ujvári, M.; Vesztergom, S.; Pénzes, C. B.; Láng, G. G. Changes of the Interfacial Stress with Electrode Potential in the $\mathrm{Ru} \mid 0.1 \mathrm{M}$ Perchloric Acid System. Electrochem. commun. 2013, 28, 111-113. https://doi.org/10.1016/j.elecom.2012.12.023

73. Ujvári, M.; Láng, G. G. Electrochemical Reduction of Perchlorate Ions. In Encyclopedia of Interfacial Chemistry; Wandelt, K., Ed.; 2018; pp 95-106. ISBN 9780128097397 https://doi.org/10.1016/B978-0-12-409547-2.13297-4

74. Szekeres, K. J.; Fekete, É.; Ujvári, M.; Vesztergom, S.; Kondratiev, V. V.; Láng, G. G. Some Observations on the Electrochemical Reactions of Bisphenol A on Polycrystalline Gold in Contact with $0.1 \mathrm{M}$ Aqueous $\mathrm{NaClO}_{4}$ Solution. Russ. J. Electrochem. 2019, 55, 1127-1135. https://doi.org/10.1134/S1023193519110132

75. Секереш, К. Й.; Фекете, Э.; Уйвари, М.; Вестергом, С.; Кондратьев, В. В.; Ланг, Г. Г. Некоторые Наблюдения Электрохимических Реакций Бисфенола А На Поликристаллическом Золоте в Контакте с Водным Раствором $0.1 \mathrm{M} \mathrm{NaClO}_{4}$. Электрохимия 2019, 55, 1381-1390. https://doi.org/10.1134/S0424857019110148 
76. Pajkossy, T.; Vesztergom, S. Analysis of Voltammograms of Quasi-Reversible Redox Systems: Transformation to Potential Program Invariant Form. Electrochim. Acta 2019, 297, 1121-1129. https://doi.org/10.1016/j.electacta.2018.12.023

77. Vesztergom, S. A Short Introduction to Digital Simulations in Electrochemistry: Simulating the Cottrell Experiment in NI LabVIEW. J. Electrochem. Sci. Eng. 2018, 8, 171-181. https://doi.org/10.5599/jese.507

78. Seeber, R.; Zanardi, C.; Inzelt, G. The Inherent Coupling of Charge Transfer and Mass Transport Processes: The Curious Electrochemical Reversibility. Chemtexts Textb. J. Chem. 2016, 2, 1-16.

https://doi.org/10.1007/s40828-016-0027-3

79. Láng, G. G. Basic Thermodynamics of Electrified Interfaces. In Encyclopedia of Interfacial Chemistry; Wandelt, K., Ed.; 2018; pp 1-14. ISBN 9780128098943 https://doi.org/10.1016/B978-0-12-409547-2.13608-X

80. Inzelt, G. Crossing the Bridge between Thermodynamics and Electrochemistry. From the Potential of the Cell Reaction to the Electrode Potential. Chemtexts Textb. J. Chem. 2014, $1,11$. https://doi.org/10.1007/s40828-014-0002-9

81. Láng, G. G. Some Remarks Concerning the Thermodynamics of the Simple Ideal Gas and Related Mathematical Background. ChemTexts 2016, 2, 10. https://doi.org/10.1007/s40828-016-0028-2
82. Láng, G. G. Basic Interfacial Thermodynamics and Related Mathematical Background. ChemTexts 2015, 1, 16. https://doi.org/10.1007/s40828-015-0015-z

83. Inzelt, Gy. Tudóssorsok és emlékmüvek. Magy. Kémikusok Lapja 2015, 70, 329-330.

84. Inzelt, Gy. Kitaibel Pál kémiai munkásságáról, egy évforduló kapcsán. Első rész. Magy. Kémikusok Lapja 2017, 72, 345-350. https://doi.org/10.24364/mk1.2017.11

85. Inzelt, Gy. Kitaibel Pál kémiai munkásságáról, egy évforduló kapcsán. Második rész. Magy. Kémikusok Lapja 2017, 72, 382-386. https://doi.org/10.24364/mk1.2017.12

86. Inzelt, Gy. A tudományos kémia és a vegyészerti iparok Magyarországon a kiegyezés időszakában. Magy. Kémikusok Lapja 2017, 72, 178-186. https://doi.org/10.24364/mk1.2017.06

87. Inzelt, Gy. Wilhelm Ostwald és a fizikai kémia születése. Magy. Kémikusok Lapja 2018, 73, 282-286. https://doi.org/10.24364/mk1.2018.09

88. Bard, A. J.; Inzelt, G.; Scholz, F. Electrochemical Dictionary, 2nd ed.; Springer: Berlin-Heidelberg, 2012. https://doi.org/10.1007/978-3-642-29551-5_ 
Improvement of electrochemical measuring systems and experimental methods, investigation of batteries, modified electrodes and electrode processes, electrochemical preparation of materials for environmental protection

The results of the Electrochemical and Electroanalytical Laboratory achieved since 2012 are summarized in this paper. Research topics include theoretical studies (e.g. thermodynamics of interfaces), investigation of electrochemical systems having peculiar properties (e.g. modified electrodes, conductive polymer films and composites), environmental protection issues (e.g. electrochemical production of ferrate salts and its application for water treatment), development of electrochemical methods, study of electrocatalysis, and many other practical applications (e.g., electrochemical power source research or electrochemical methods in organic chemical research).

Measurements were carried out using the bending beam method for the investigation of the surface stress changes of ruthenium in perchloric media and the degradation of conducting polymer layers deposited on metal surfaces. Dual voltammetry was applied for the study of the oxygen reduction on gold and for the corrosion of titanium. Theoretical studies and simulations of potentiodynamic RRDE measurements were performed and new methods for the mathematical modeling of the so-called electrical crosstalk were developed. The modeling methods are also applicable to other types of multielectrode systems (e.g. scanning electrochemical microscope).

$\mathrm{Fe}-\mathrm{Pd}$-and $\mathrm{Cu}$ - phthalocyanine layers were deposited and their catalytic effect for oxygen reduction was investigated as a possible replacement of platinum catalysts. The lead batteries came also into foreground: charging-discharging characteristics and the formation and ageing of the $\mathrm{PbO}_{2}$ layer were studied. In case of $\mathrm{Li}$ ion batteries the effect of the binder material of the cathode was discussed. Nanogravimetric measurements were carried out on multiwalled carbon nanotubes which can be used in supercapacitor applications.

Modified electrodes are systems in which a layer of novel properties is deposited on an electron conductor or semiconductor substrate. In the Laboratory of Electrochemistry and Electro-analytical Chemistry several types of modified electrodes were prepared and investigated in the last years, including polymer, yeast and phthalocyanine modified electrodes. During the study of the oxidized PEDOT (poly(3,4-ethylenedioxythiophene)) film it was observed that the impedance changes with time. After overoxidation of the polymer, at both high and medium frequencies the complex-plane plot of the measured data was characterized by a "capacitive" arc (or depressed semicircle), while the low frequency part indicated "capacitive" behavior. However, the complex plane plots clearly indicated that the system is nonstationary. E.g. it could be inferred from the shapes of the sequentially recorded impedance data sets that the charge transfer resistance at the substrate/polymer film interface decreases continuously over several hours. The impedance analysis results showed that the so-called "4-dimensional analysis" (FDA) method can not only be used for the correction of the existing (experimentally measured) impedance data, but it opens up the possibility of the estimation of the impedance spectra outside the time interval of the impedance measurements. The effect of the storage conditions of the EDOP (3,4-ethylenedioxypyrrole) monomer to the formed polymer film was also studied.

The nanogravimetric method proved to be effective in the mechanistic investigation of formation and redox transform of polyaminoindoles, yeast and phthalocyanine modified electrodes.

Electrocatalysis is also a main research topic of the Laboratory: several papers dealing with electrochemical $\mathrm{CO}_{2}$ and oxygen reduction, adsorption processes on platinum, electrochemical deposition of ternary alloys and mechanism of electrochemical hydrogen evolution were published.

We conducted more research which has importance from environmental point of view. The ferrate salts are strong oxidative agents therefore can be effectively used for wastewater and/or drinking water treatment, but the handling is problematic because of their reactivity if in contact with air or humidity. In the framework of industrial cooperation electrochemical method capable for producing large amounts of sodium and potassium ferrates has been developed which is, even for on-site production solving the storage and transport problems. The effectivity of the ferrate ions in wastewater treatment was investigated by our partners in case of trichloro-ethylene and chloro-benzenes removal. Another environmental protection issue is the perchlorate contamination of the drinking water. The electrochemical reduction of perchlorate reduction was studied as a possible solution for the problem. Bisphenol-A (BPA) is a carcinogen compound and can be often present in polycarbonates, inner coating of metal food cans. It was shown that during voltammetric measurements in BPA containing solutions the polymerization and degradation of BPA occurs simultaneously. The formed polymer is adherent, smooth, and electrochemically inactive. 